\title{
PLAYING WITH TECHNOLOGY IN EARLY CHILDHOOD EDUCATION: CREATION OF A PLAY CENTER
}

\author{
M. Figueiredo ${ }^{1}$, S. Santos ${ }^{2}$, B. Rego ${ }^{1}$ \\ ${ }^{1}$ Polytechnic of Viseu, School of Education and CI\&DEI (PORTUGAL) \\ ${ }^{2}$ Polytechnic of Viseu, School of Education (PORTUGAL)
}

\begin{abstract}
A study was developed in the context of a Master's Degree in Early Childhood and Primary Education about the meanings children in Early Childhood Education attribute to technology in the context of creating and exploring a play center. Twenty children between 3 and 6 years-old were involved in the qualitative study and were part of the creation of the center and played in it. The play center was created by the children through a project approach that researched about technology in their daily life. The play center afforded the role of users but also repair specialists, knowing how technology works "from the inside". The results suggest that the diversity of electronic devices and the possibilities of manipulation and free exploration in the context of playing allowed children to develop a diverse relationship with technology that included agency and specific knowledge related to the components, and technical and social usage of the devices.
\end{abstract}

Keywords: Early childhood education, technology, play, pedagogy, children's perspectives.

\section{TECHNOLOGY, PLAY, AND PEDAGOGY}

Technology is an important part of what children experience in their daily life and in formal contexts like Early Childhood Education. For the Portuguese Curricular Guidelines [1], technology is part of the curricular area Knowledge of the World. This take on technology as including different technological devices as well as contexts and uses is larger than the usual concept of "educational technology" that usually refers to computers, interactive whiteboards and tablets. The research on technology in Early Childhood Education is also adopting a more inclusive view of digital devices [2]. It's acknowledged that the contexts, phenomena, and relationships that children connect with are technology-laden and, therefore, children should learn about technology and have a good and critical relation with it. The introduction of technology in Early Childhood Education schools needs, therefore, to be intentional and pedagogical.

A synthesis of the position statements, reports, research reviews, guidelines, and recommendations about technology in Early Childhood Education released in the last decade identifies strong agreement on a set of 10 foundational elements necessary for successful technology integration with young children [3]. From those, we highlight:

a) Relationships-A child's use of media and technology should invite and enhance interactions and strengthen relationships with peers, siblings, and parents.

b) Social and emotional learning-Technology should be used in ways that support positive social interactions, mindfulness, creativity, and a sense of initiative.

c) Early childhood essentials-Technology use should not displace or replace imaginative play, outdoor play and nature, creativity, curiosity and wonder, solitary and shared experiences, or using tools for inquiry, problem solving, and exploring the world.

d) Adult habits-As the primary role models for technology and media use, adults should be aware of and set limits on their own technology and media use when children are present and focus on children having well-rounded experiences, including moderate, healthy media use.

A primary recommendation is that technology is part of the pedagogical approach and therefore is incorporated with other elements and is planned and reflected with the same principles and conceptions that guide practice.

Early Childhood Pedagogy is based on children's rights and includes several dimensions: interactions between children and adult and the organization of the context where those interactions take place [4]. This context is physical, including the space and the materials, but also relational and functional. In terms of interactions, listening to children about their experiences and interests and opportunities for 
rich and meaningful play are important [5]. The first allows for activities that are presented and directed by the adult to be relevant for the children and promote meaningful learning. The second is an important tenet of Early Childhood Pedagogy as play is a crucial way of learning for children. In this study, children's play was assumed to be essential for learning [1], [6]-[8], also within the scope of technology [9]-[11].

Practitioners and children, when talking about children playing with computers, usually refer to children using computers during playtime performing a series of different activities (associated with different types of software, including computer games) [12], [13]. Computer use is often something that may be allowed between planned or adult-led activities, which means that it is typically used during the time that is organised as free play [14]. The same holds true about other technologies, but playing with technology is not as restrictive and includes everyday technological objects and toys [9] that can be used in play as cultural tools [15]. Playing with technology as a way of building meaning about technology in society, therefore, includes playing beyond the use of that technology, incorporating it in interpretative reproductions [16].

\section{METHODOLOGY}

Data collection took place in a public Early Childhood Education (ECE) school in Viseu, with 20 children between 3 and 6 years old. The school had five groups of ECE and 12 classes of Primary Education. The teacher had a long experience of working with children and was in the school since it had opened. The study was developed by a student teacher from the Master's Degree in Early Childhood and Primary Education that was assigned to this class for her five months-long practice. Data collection started two months before the end of the practicum when a good relationship with the children had already been developed. Data collection and analysis were guided by the purpose of identifying the meanings children attribute to technology in the context of creating and exploring a play center.

The descriptive study was based on participant observation and interviews with children [17]-[20]. The creation of the play center was preceded by short interviews with children about technology in their lives. The interviews were informal and took place in the classroom, during the normal daily routine. Permissions were obtained from the parents and also from the children [21], who were asked if they wanted to help with a special assignment.

After analyzing the preliminary data, a project approach was prepared and initiated. The project approach involves children's in-depth investigation of a relevant topic developed through authentic questions [22]. Throughout the process, the teacher's role is to support children through their inquiry, preparing in advance and analysing the educational and learning potential of the experiences. On a more day-to-day level, teachers help children become responsible for their work, authors of their learning, guide them to document and report their findings, and provide opportunities for choice [23].

The planning was flexible and the project resulted in the involvement and participation of children in the reconstruction of the educational space of the activity room to create the "Let's repair ICT" play center that had several real devices (laptops, PSP, tablets, mobile phones, flash drives) for makebelieve situations, allowing interpretative reproductions of children's experiences.

\section{RESULTS}

\subsection{Preliminary ideas about technology}

The computer and the mobile phone were identified as such by all children. Both devices were associated with adults, as children were able to report having seen different adults using them. They did not think of themselves as users of the computer nor the mobile phone. Photos of several ICT devices were shown to the children and small conversations about them were held. Besides the computer and the mobile, children were shown a tablet, a Portable Playstation (PSP), headphones with a microphone, a flash drive, and an external hard-drive. The last two were not easily identified. Only one child recognized that a flash drive is something adults use. None suggested the hard-drive was used by anyone.

There was a personal computer in the classroom that children used for games and small searches. It was also associated with playing music videos for dancing. Since $25 \%$ of the children recognized but weren't sure about how tablets were used, some tablets were presented to the children. In small 
groups or pairs, they had the opportunity to play some games and explore the interface and interaction with tablets (Fig. 1).

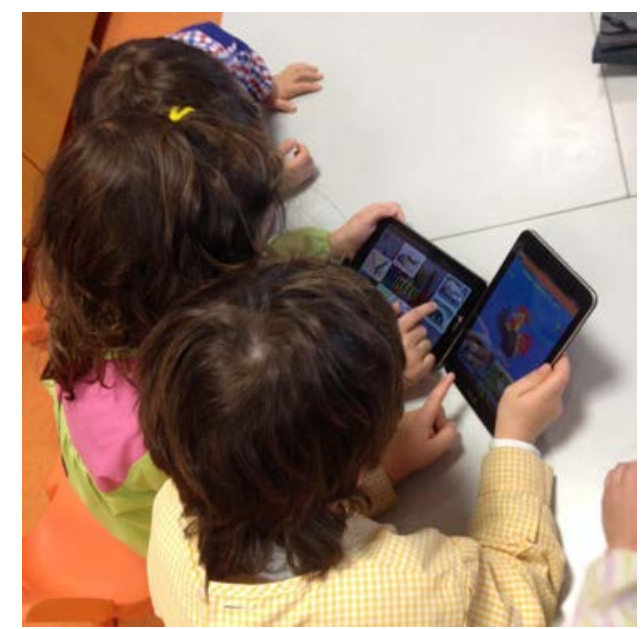

Figure 1: Children using tablets in the ECE classroom

\subsection{Creating a space for playing with technology}

The small conversations held and the opportunity to use the tablets engaged children in discussions during large group time about ICT. The teacher showed interest in keeping the conversation alive, and started writing down what was known and the questions children were raising. This documentation was necessary to gather disperse ideas that were shared in different times of the day. When a significant number of children had contributed with their knowledge and there was a common interest in one aspect of the topic, the teacher suggested that the group started searching for more information about it. Children showed high levels of engagement [24] during these moments and activities. There was widespread interest in how things work and why do they sometimes stop working. Children reported small narratives about adults being upset about non-functioning devices.

A first idea about how to learn more about the topic was to gather several devices so they could be explored, compared and analyzed. A written request to parents and other classrooms was prepared by some children and sent out. Several devices that were outdated were collected. Children enjoyed having them in the room and manipulating them. The fact that most of them were not working only increased the interest in those phenomena. The adults suggested that someone who was used to repairing technology could help us with our questions. A technician was invited to come to the classroom and brought some of his tools with him (Fig. 2). His visit was very instructive and children were highly involved during the different moments. The tools were a focus of attention but also the inside of computers that was made visible by removing covers.

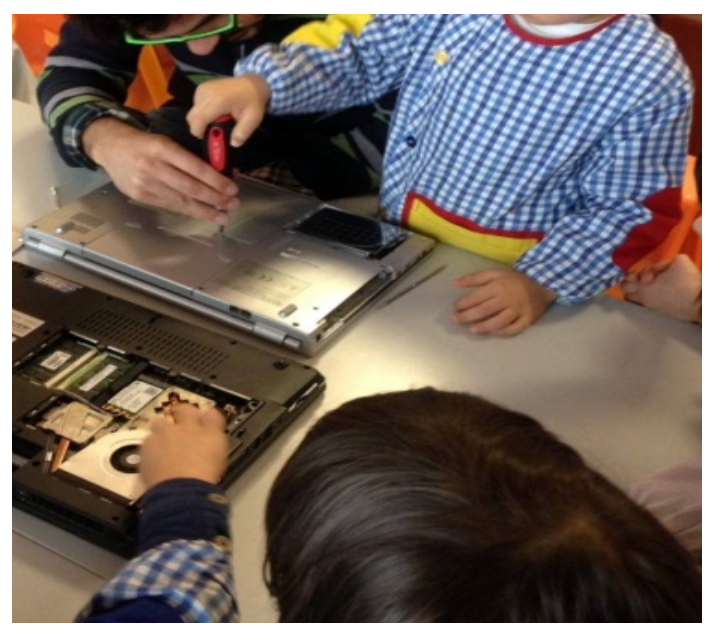

Figure 2. Using tools to open the laptop during the visit of the technician. 
The next step was decided based on a discussion conducted by the teacher: we have the the pieces of equipment, you'd like to play with them more, what can we do to solve the problem? Children started suggesting a play center. Different ideas were presented but the repair shop was the most engaging. The process of planning the center was, from then on, led by the children, who started working on a name ("Let's repair ICT") and a logo and poster to be on the space itself. Furniture and materials from other play areas were brought into the space that was chosen (Fig. 3).

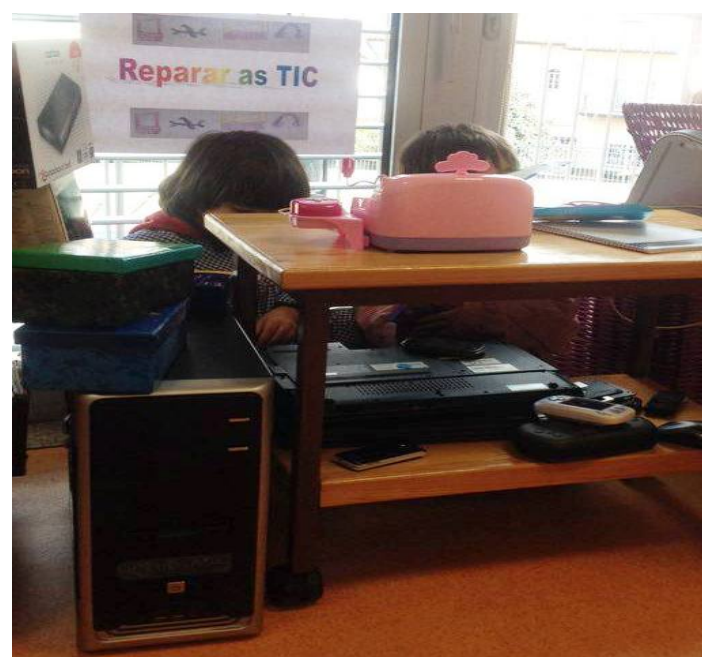

Figure 3. A view of the play center.

The enthusiasm was high and contagious. A new request for ICT and tools was shared with families that were now aware of the new space. The concept of a shop, requiring payments, justified that the registration was borrowed from the grocery shop to this new shop. Different ways of organizing the devices were tested. The way o better store the tools was also discussed. There was a concern that repaired devices would be mixed with broken ones. A color code was implemented: red for in need of repair, green for repaired.

Throughout these decisions, children never stooped playing with the devices themselves. This was make-believe play as none of the ICT was working. It was observed that children created several situations involving the computer, the mobile or the tablet.

After the play center was set up, it was officially considered as one of the play centers that could be chosen by the children to play in during playtime (Table 1).

Table 1. Synthesis of project activities per phases

\begin{tabular}{c|l}
\hline \hline \multicolumn{1}{c|}{ Phase } & \multicolumn{1}{c}{ Main activities } \\
\hline I- Beginning & $\begin{array}{l}\text { Presentation/discussion of devices and list of ideas about "what to learn more about ICT" } \\
\text { Building a list of the necessary materials and requests for collaboration to obtain equipment }\end{array}$ \\
\hline II- Developing & $\begin{array}{l}\text { Visit of a computer technician and learning about repair processes and tools involved } \\
\text { Decision about creating the play area (repair shop) and choosing a name and a logo for it } \\
\text { Discussion and experimentation with alternatives for organizing the equipment in the shop } \\
\text { New list of required materials - interaction with the public }\end{array}$ \\
\hline \hline III - Concluding & $\begin{array}{l}\text { Final assembly of the shop } \\
\text { Including the shop as one of the playing areas available at playtime to be chosen }\end{array}$ \\
\hline \hline
\end{tabular}

During three weeks, the way children played was observed as part of the data collection. It was possible to see a mixture of real and make-believe objects in the play (Fig. 4). 


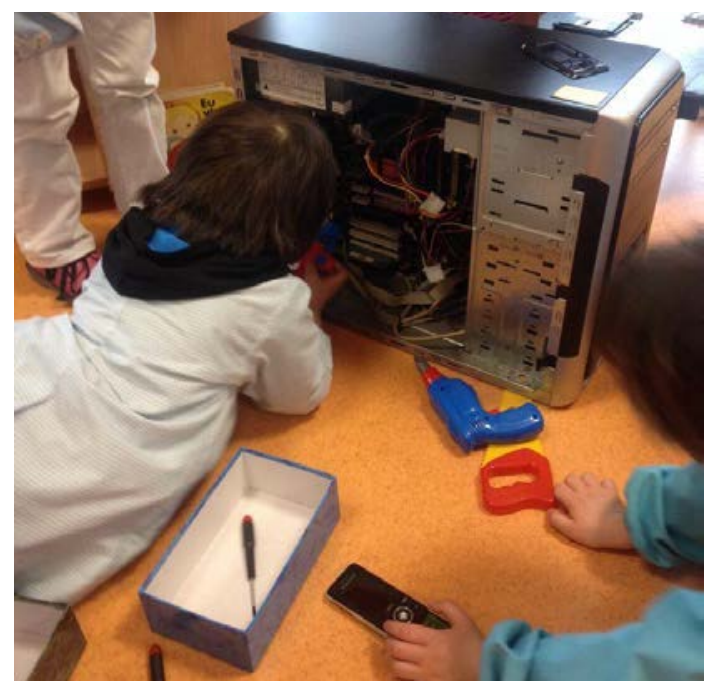

Figure 4. Real and plastic tools mixed in play.

The repair activity started to take precedence over play that used the devices in other situations. Opening up the devices and looking for problems was the main ingredient (Fig. 5).

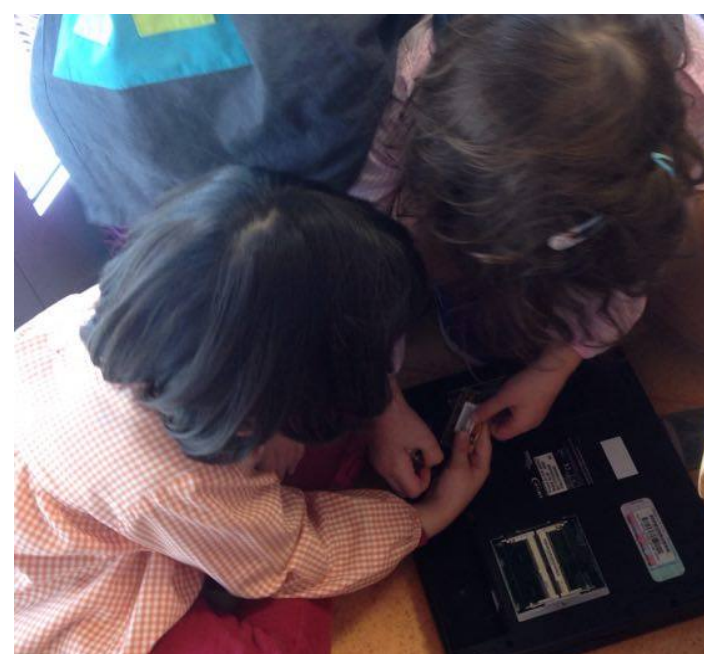

Figure 5: Playing at repairs.

\subsection{Learning and meaning}

The project approach was engaging for all children. There were different direct experiences with technology that made the contribution of everyone relevant. Children posed several questions and wanted to test a myriad of things. It was particularly positive that the devices and the play center allowed for manipulation, testing of hypotheses, and demonstration of ideas during the discussions.

Besides the enthusiasm and motivation during the creation of the new play center, children enjoyed playing in it. It was one of the most chosen areas during playtime. Overall, the way children played with technology opened opportunities for exploration, manipulation and experimenting [25].

The play that was developed was engaging and rich mostly because there were many experiences and knowlege that children could use to feed their play and exchange between themselves during the play, co-constructing meaning. The problems that the clients complained about, the defects that were reported, the accidents that were explained were diverse and creative. The repairing solutions were also intensely invested by the children. The technological devices in the play center were always used maintaining their identity. The imagination about problems and solutions was based on the fact that those devices were technology that was familiar to the children. Accordingly, the laptop, the CPU and the mobile devices were the most included in the play. But other devices were also used: the PSP was 
part of "playing games", a smooth cloth was used to clean a CD "that had been scratched", showing recognition for the fragility of the support.

\section{CONCLUSIONS}

One first strong idea is about how play is a powerful context for meaning making. Children developed their knowledge with contribution from others, manipulated and tested ideas and showed high levels of involvement [24]. Play was also a very relevant context for observing children and learning about their experience and knowledge about ICT.

The play center afforded the role of users but also repair specialists, knowing how they work "from the inside". The results suggest that the diversity of electronic devices and the possibilities of manipulation and free exploration in the context of playing allowed children to develop a diverse relationship with technology that included agency and specific knowledge related to the components and technical and social usage of the devices.

A particular idea started to show in the play: devices are composed of parts and sometimes things don't work because of missing or damaged parts. This is a powerful idea for learning about technology and systems [26]. Another powerful idea or purpose [27] that came across children's play was that tools help achieve tasks and procedures that otherwise would be complicated or impossible.

Finally, children showed confidence in using and exploring the devices, which is important for technological fluency, but also in the role-playing of users and repairers of technology, dealing with problems with an attitude of analysis and solution-seeking that was inspiring of a problem-solving approach.

\section{ACKNOWLEDGMENTS}

This work was funded by National Funds through the FCT-Foundation for Science and Technology, I.P., within the scope of the project ref: UIDB/05507/2020. Furthermore, we would like to thank the Centre for Studies in Education and Innovation (CI\&DEI) and the Polytechnic of Viseu for their support.

\section{REFERENCES}

[1] Ministry of Education, Curricular Guidelines for Early Childhood Education. Lisbon: Ministerio da Educação, 2016.

[2] C. Jack and S. Higgins, 'Embedding educational technologies in early years education', Research in Learning Technology, vol. 27, no. 0, 2019, doi: 10.25304/rlt.v27.2033.

[3] C. D. R. Schomburg, 'Technology and Interactive Media in Early Childhood Programs: What We've Learned from Five Years of Research, Policy, and Practice', Young Children, vol. 72, no. 4, 2017.

[4] M. P. Figueiredo, H. Gomes, and C. Rodrigues, 'Mathematical pedagogical content knowledge in Early Childhood Education: tales from the "great unknown" in teacher education in Portugal', European Early Childhood Education Research Journal, vol. 26, no. 4, pp. 535-546, 2018, doi: 10.1080/1350293X.2018.1487164.

[5] M. P. Figueiredo, 'Estudos no âmbito da Pedagogia de Infância', in Olhares sobre a Educação: em torno da formação de professores, L. Menezes, A. Cardoso, B. Rego, J. P. Balula, M. Figueiredo, and S. Felizardo, Eds. Viseu: Escola Superior de Educação de Viseu, 2017, pp. 178181.

[6] I. Pramling-Samuelsson and M. A. Carlsson, 'The playing learning child: towards a pedagogy of early childhood', Scandinavian Journal of Educational Research, vol. 52, no. 6, pp. 623-641, 2008.

[7] I. Pramling-Samuelsson and M. Fleer, Play and learning in Early Childhood settings. International perspectives. Nova lorque: Springer, 2009.

[8] E. Wood, 'Developing a pedagogy of play', in Early Childhood Education: Society and Culture, A. Anning, J. Cullen, and M. Fleer, Eds. Londres: SAGE, 2004, pp. 19-30. 
[9] K. Nikolopoulou and V. Gialamas, 'ICT and play in preschool: early childhood teachers' beliefs and confidence', International Journal of Early Years Education, vol. 23, no. 4, pp. 409-425, 2015, doi: 10.1080/09669760.2015.1078727.

[10] F. Aldhafeeri, I. Palaiologou, and A. Folorunsho, 'Integration of digital technologies into play-based pedagogy in Kuwaiti early childhood education: teachers' views, attitudes and aptitudes', International Journal of Early Years Education, vol. 24, no. 3, pp. 342-360, 2016, doi: 10.1080/09669760.2016.1172477.

[11] S. Edwards, 'New concepts of play and the problem of technology, digital media and popularculture integration with play-based learning in early childhood education', Technology, Pedagogy and Education, vol. 25, no. 4, pp. 513-532, 2016, doi: 10.1080/1475939X.2015.1108929.

[12] L. Plowman and C. Stephen, 'Children, play, and computers in pre-school education', Br J Educ Technol, vol. 36, no. 2, pp. 145-157, 2005, doi: 10.1111/j.1467-8535.2005.00449.x.

[13] J. Howard, G. E. Miles, and L. Rees-Davies, 'Computer use within a play-based early years curriculum', International Journal of Early Years Education, vol. 20, no. 2, pp. 175-189, 2012, doi: 10.1080/09669760.2012.715241.

[14] M. P. Figueiredo, A. Figueiredo, and B. Rego, 'Peer interaction in mixed age groups: a study in the computer area of an early childhood education center in Portugal', in ICERI2015 Proceedings, Seville, Spain, Nov. 2015, pp. 2548-2554.

[15] L. Amante and Á. Faria, 'Sentidos(s) emergente(s) das tecnologias digitais no jardim de infância', in Ensinar e aprender online com tecnologias digitais: abordagens teóricas e metodológicas, J. A. Moreira and A. Monteiro, Eds. Porto: Porto Editora, 2012, pp. 45-62.

[16] W. A. Corsaro, 'Interpretive reproduction in children's role play', Childhood, vol. 1, no. 2, pp. 6474, 1993, doi: 10.1177/090756829300100202.

[17] P. Christensen and A. James, Eds., Investigação com crianças: perspetivas e práticas. Porto: Edições Escola Superior de Educação de Paula Frassinetti, 2005.

[18] W. A. Corsaro, 'Entrada no campo, aceitação e natureza da participação nos estudos etnográficos com crianças pequenas', Educ. Soc., vol. 26, no. 91, pp. 443-464, 2005, doi: 10.1590/S0101-73302005000200007.

[19] M. E. Graue and D. J. Walsh, Investigação etnográfica com crianças: teorias, métodos e ética. Lisboa: Fundação Calouste Gulbenkian, 2003.

[20] S. Cruz, 'A qualidade da educação infantil, na perspetiva das crianças', in $A$ escola vista pelas crianças, J. Oliveira-Formosinho, Ed. Porto: Porto Editora, 2008, pp. 75-93.

[21] S. Kramer, 'Autoria e autorização: questões éticas na pesquisa com crianças', Cadernos de Pesquisa, vol. 116, pp. 41-59, 2002.

[22] L. G. Katz and S. Chard, $A$ abordagem de projeto na educação de infância. Lisboa: Fundação Calouste Gulbenkian, 1997.

[23] L. G. Katz and S. Chard, 'The Project Approach: An Overview', in Approaches to Early Childhood Education, J. Roopnarine and J. E. Johnson, Eds. Upper Saddle River, NJ: Pearson, 2013, pp. 268-284.

[24] G. Portugal and F. Laevers, Avaliação em Educação Pré-Escolar - Sistema de Acompanhamento das Crianças, 2nd ed. Porto: Porto Editora, 2018.

[25] M. Miranda and A. J. Osório, 'As TIC no Desenvolvimento de Comunidades de Prática e na Formação de Educadores - o Caso da ArcaComum', in O digital e o currículo, P. Dias, A. J. Osório, and A. Ramos, Eds. Braga: Centro de Competência da Universidade do Minho, 2009, pp. 31-50.

[26] M. U. Bers, Coding as a playground: Programming and computational thinking in the early childhood classroom, 2nd ed. New York: Routledge Press, 2021.

[27] A. C. McAninch, 'Continuity and Purpose in the Design of Meaningful Project Work', Early Childhood Research \& Practice, vol. 2, no. 1, 2000. 